\title{
3. 'Skirts-Money-Masks', and Other Chains of Masculine Signification in Post-Colonial Papua New Guinea
}

\author{
David Lipset
}

This is our starting point: through his relationship to the signifier, the subject is deprived of something of himself, of his very life, which has assumed the value of that which binds him to the signifier. The phallus is our term for the signifier of his alienation in signification. (Lacan 1977a:28)

\section{Introduction: The Lacanian phallus in a post- colonial setting}

With revision, the Lacanian phallus - qua concept of the subject in culture as based on a void of meaning - might also serve as a starting point for this chapter. Here, however, I do not intend to theorise the emptiness of the subject in an abstract, psychoanalytic sense. Instead, my conceptual and empirical focus is on a particular group of rural, post-colonial men. Specifically, this chapter concerns shifting signifiers of masculinity in the Sepik region in Melanesia, this being the issue and region that so vexed Tuzin (1997) in his magisterial account of the demise of the male cult in Ilahita village. To begin, I must briefly explain why, among all the decentred concepts of personhood and gender in society (see, for example, Dumont 1986; Durkheim 1933-97; Leenhardt 1979), I prize the Lacanian phallus.

First of all, notwithstanding its masculine register, the Lacanian phallus does not stand for itself in any simple kind of way. It is, yet it is not, the male organ. Instead, the phallus is a symbol of symbols - a master signifier that nevertheless does not define reality/discourse in and of itself, as patriarchy might be said to do. It is a trope established by 'desire of the other, not so much because the other holds the key to the object desired, as because the first object of desire is to be recognized by the other' (Lacan 1977b:58). Initially, the phallus, qua signifier, comes into being as the object of maternal desire. 'If the desire of the mother is the phallus, the child wishes to be the phallus in order to satisfy that desire' (Lacan 1977b:289). In other words, the Lacanian phallus is defined relationally (see also Strathern 1988) and its relationality is based on an impossible, unfulfillable 
desire. For Lacan, the lack of the other leaves an indelible trace in the subject, a trace that constitutes yet subverts subsequent chains of signification in which persons and objects are substituted for, or superimposed upon, her absence and missing desire for her desire that motivates their meaning.

The entry into culture - for example, the domain Lacan calls the Symbolicbasically arises from an oedipal injunction; a taboo, to be sure, but one that does not result from the intervention of the father himself. It results, according to Lacan, from what amounts to a semiotic substitution, a substitution of the "name of the father' (1977b:67) for the love and desire of the mother. This substitution both is and opens up the world of language, law and social action. The Name-ofthe-Father, that is, is discursive rather than literal. With the symbolic lack of the imaginary object - the mother's desire - the phallus is 'castrated' (1977b:289). The absence of the other makes signification possible, signification in which, like the male cult, the phallus might misrecognise itself, and be misrecognised, as a powerful and self-sufficient subject or as an illusory kind of gift, albeit one that can never be repaid, much less unilaterally possessed. The 'function of the phallus is to pass for the signifier of the desire of the other' (Nobus 1999:113).

While its relational construction, its gender, detachability and ambiguous position as master-signifier make the Lacanian phallus a useful template for a reconsideration of masculinity in Melanesia, its most trenchant attribute is its irretrievable, yet ambivalent, dispossession from desire, its absent centre. The phallus is associated with the loss of pleasure. But the register in which Lacan casts this alienation is not single toned. The phallus is signified in people and things that represent both presence and absence at once. Again, like male cult spirits, the phallus is an emptiness that appears as a force in society, thus to divide, or subtract, women from men by virtue of its illusions. Its modality is one of combination, mixture and incongruity consisting of rupture and continuity, melancholy and optimism. 'The phallic signifier', as Žižek phrased this contradictory quality, is 'an index of its own impossibility. In its very positivity it is the signifier of "castration" - that is, of its own lack...In the phallus, loss as such attains a positive existence' (1989:157).

Post-colonialism, however - the condition of authority in societies emerging from the experience of colonisation (Mbembe 1992) - as distinct from postcolonial critiques of hegemonic discourse (Said 1978; Young 2001), requires modification of the Lacanian phallus. Amid post-colonialism, everythingevery illusory signifier of legitimacy - is pluralised. Instead of a singular Nameof-the-Father, multiple languages, names, cosmologies, laws, medical systems, currencies, and so forth coexist, perhaps in competition with each other, as rival signs of equivocal intervention. So instead of one Symbolic into which the phallus is castrated and exiled, I posit two Symbolics, both of which take their cut from the 'very life' of the subject, thus to 'bind him to the signifier'. Two 
Names-of-the-Father - that is, two discursive bodies - 'symbolically castrate' the phallus, thus to doubly bind him to very different sorts of signifiers of his alienation. Together, the two Symbolics - the many pre-state, pre-capitalist ones, and that of modernity - give rise to unpredictable, complicated chains of signification. In my view, the former are not eliminated by the latter. Instead, the register of these chains is not just tragic, joyless and dismembered. However impossible or inaccessible they might be, the post-colonial scene remains full of objects of desire for the subject. Their circuit of meanings is positive and productive as well as empty. Of course, this is not quite how Tuzin viewed the fate of the male cult in Ilahita (and see also Knauft, this volume).

\section{Wither Masculinity in Ilahita?}

Recall the ingenious trope at the centre of Tuzin's argument in The Cassowary's Revenge (1997): the myth of Nambweapa'w foretold the retaliation of (fundamentalist Christian) women against the deceit of the male cult! The voice, in other words, with which Tuzin identified was that of culturally conservative masculinity, rather than that of the Christians or with their particular male and female constituencies. For Tuzin, the deliberate revelation of the secrets of the Tambaran cult by millenarian evangelicals in 1984 devastated its members and led to anomie in society at large. Among the many consequences, the male cult lost its position as the object of desire in society. Men stopped planting long yams for competitive ceremonial exchange. They stopped building cult houses. They stopped initiating male youth. The quality of their oratory declined. With men deprived of their sacred rationale for solidarity, domestic violence between husbands and wives increased. No longer under the authority of cult elders, male youth entered into other forms of criminal behaviour as well. Meanwhile, female prophets accused men of being polluted by sexual infidelities. Expectations of how much money was appropriate in mortuary exchanges to honour the dead, and especially men, became ambiguous. Food production dropped. Disease spread through the community.

A grim, melancholy picture, to be sure, but The Cassowary's Revenge might also serve as an account of the relationship of the phallus to the two Symbolics I discussed above. If the Name-of-the-Father never totally severs the phallus from the other, but leaves him in an impossible state of desire in which objects create more desire to the extent that they inevitably fail to fulfil desire, perhaps the injunction against the Tambaran that modernity - represented by Christian revivalism - managed to occasion, might be interpreted in a less catastrophic register. A discussion of what subsequently took place would vindicate mefor example, the revival of the male cult, in whole or in part. But I do not know what has happened in Ilahita since 1985. So instead of reanalysing The 
Cassowary's Revenge, I turn to the fate of ritual masculinity in another Sepik setting: the Murik Lakes in the estuary of the great river, where I have done research since $1981 .{ }^{1}$ In Murik, modernity has not 'killed' the male cult. Rather, men improvise improbable, unforeseen chains of substitution.

So as to develop this rather abstract point ethnographically, I proceed as follows. I will first sketch Murik concepts of personhood. I then introduce the Gaingiin Society, a public, age-graded society in which rights to senior masks used to be exchanged in return for wives' sexual services. In the next section, I go on to analyse a moment in 1988 when money was substituted for sexual intercourse during a grade taking. In conclusion, I argue that this substitution took place in a broader context in which the pre-state phallus is combining metaphorically with the modern, rationalised phallus in several ways rather than just the single, tragic modality that Tuzin reported in Ilahita. ${ }^{2}$

\section{The Embodiment of Murik Personhood}

Domestic community consists of multiple cognatic lineages domiciled in clusters of households of siblings and their extended families. While persons define themselves and are identified in terms of and through kinship (see Lipset and Stritecky 1994), embodiment and the relationship of personhood to the body are distinctive and need to be spelled out in a little detail.

Embodiment is based on three assumptions. One differentiates it through acts of nurture. Parents give food to children (Barlow 2010). They are then understood not to grow 'big' or 'strong' for having eaten but to become indebted to them both sentimentally and ritually for having benefited from their 'hard work' (Barlow 1985). A second indication of embodied identity is aesthetic. Gifts of ancestral insignia (sumon) are ritually bestowed. The body is recognised as possessing several important internal sites: its blood, stomach, semen for men, and the womb and breast milk for women. Rather than fixed at birth, however, the jural person is defined by an ensemble of shell and teeth ornaments, as well as other accessories, that decorates the body. Rank in the lineage is signified by conferral of an outfit of individually named sacra, one of which might serve as a metonym for the whole, usually its basket (sumon suun) and/or a medallion made of boars' tusks and bird-of-paradise plumage. These insignia are entrusted to firstborn members of their senior sibling groups who bestow them upon kin during rites of passage and are otherwise obliged to protect them from exposure

\footnotetext{
1 Tuzin himself had suggested that my ex-wife, Kathleen Barlow, and I might find the Murik Lakes an interesting setting to research.

2 It is commonplace to view post-colonial masculinity in Papua New Guinea as a historical tragedy (Brison 1995; Knauft 2002; Robbins 2002; Wardlow 2006; Zimmer-Tamakoshi 1997).
} 
to conflict, which pollutes the paraphernalia. The key point here is that the rank and identity are viewed as having to be presented to the bodies of kin. Of course, they are not given at random. They are transacted in return for the ritual work donors received from previous generations, which reciprocity defines the jural body (Lipset 1990).

If its exterior is an object upon which personhood is bestowed, qua food and sacred ornamentation, then, to a certain extent, its interior is understood as a vehicle. The subject, in this latter sense, is said to be a spirit (nabran) in a canoe-body (gai'iin) carrying or transporting insignia. The entailed sequence of boarding, departing, passing through a kin or ancestor-based channel, travelling over the water, arriving, or coming ashore at the appropriate, kin-based dock, and disembarking from a vehicle all foreground the spatial mobility of the spirit-subject, but also its separability or detachability from the body-again, to invoke Marilyn Strathern's (1988) phrasing of Melanesian embodiment. In daily life, when human spirits (nor) paddle across the Murik Lakes, or travel up the coast to Wewak, the town market, they put this schema-of movement, but also of their being in society - into practice.

This concept of vehicular embodiment reaches beyond ordinary, daily life and is applied cosmologically. At the same time as people voyage, ancestor spirits venture through the lacustrine/marine space in their own zoomorphic canoebodies, such as fish-canoes (tand gai'iin) or bird-canoes (pise gai'iin), among many others - canoe-bodies that they may board and then disembark upon reaching their destinations so as to return to their humanoid canoe-bodies (Lipset 2009:63). Similarly, when human spirits dream, they leave their canoebodies to move about in other canoe-bodies with the spirits of other kinmostly dead-before returning to their human vehicles, say, at dawn when they get up from under their mosquito nets. That is, dream life is another instance of canoeing. In these and other ways, the Murik subject is viewed as composed of multiple canoe-bodies that people get into and out of for the purposes of travelling to and from kin and the market.

There is another, occult meaning of the canoe-body. From a masculine point of view, but not necessarily a feminine one (see Barlow and Lipset 1997), the canoe-body is associated with the phallus. Outrigger-canoe logs are ritually transformed from female to male when they are cut down. Carving requires chastity that mystically empowers the canoe-bodies of the carpenters at work. Their chastity also safeguards the integrity of the wooden hull from sexual pollution by women. Canoe prows are intricately adorned with phallus-like motifs (see Lipset 2005). Overseas voyages of outrigger canoes were protected by the chastity of the helmsman's wife (Barlow 1985). And, in the aftermath of a phase of male initiation, when a father learned that his son had stoically withstood the pain of having a sharp blade of a palm of sword grass inserted into 
and yanked out of his urethra (to show him how to expel the impure feminine blood contacted during intercourse), he might exclaim: 'Oh! My canoe has come shore!' (Lipset 1997:280).

The embodiment of the person/subject in general, and the phallus in particular, is thus imbued with vehicular, spatial and transactional meanings; and, vice versa, canoes are informed with phallic embodiment. These ideas coalesce into a single image. When a son is born, kin are said to observe with relief, 'he will take his father's place' (yan kaban osangait). The image of 'taking his place' acknowledges that youth may and should succeed age in occupation of, or claim to, the latter's status, rights and obligations. But it also acknowledges that this succession is contingent upon reciprocal agency: it must be given and taken. This view of reproduction as generational substitution is not, however, understood as reincarnation or biological regeneration. It is rather imagined in an idiom of kin-based expectation that further action will result in 'replacement' (cf. Weiner 1980). This idea has widespread application. The point is that the three images - of generational succession as 'taking the place of', the canoebody-phallus association and the bestowal of rank-combine to form a concept of action as the replacement of passengers travelling in decorated canoe-bodies through hereditary channels. A son or daughter thus becomes a metaphor in the social structure for his or her same-sex parent as actor and node of relationships for the parent. In Murik terms, a heir is sometimes said to be her mother's or his father's 'canoe'. In this pre-state concept of personhood, the metaphor of reproduction is simultaneously the reproduction of a metaphor, of a heir who should take over steering a canoe-body. Simultaneously, it is a cultural assertion that substitution is not only possible, but is a solace.

From a Lacanian viewpoint, of course, such an unequivocal view of reproduction is just half the story. In addition to relief, the appearance of a heir should also give rise to an expression of Non! by which the Name-of-the-Father metaphorically expels the phallus into the Symbolic or culture. For Lacan, culture cuts the phallus off from the desire of the other - a symbolic castration that motivates the subject's commitment to language, convention and law, on the one hand, but also recreates this originary oedipal intervention and the eternal gap between the pleasure of maternal acknowledgment and the impossibility of its retrieval, on the other. We shall now see that the Murik do indeed value reproduction, which is to say, 'replacement', as both a consolation and a loss of the other. To document this contradiction, I turn to the public masquerade I call the Gaingiin Society. 
3. 'Skirts-Money-Masks', and Other Chains of Masculine Signification in Post-Colonial PNG

\section{The Gaingiin Society, or 'The Name of the Father' in the Post-Colonial Moment}

The Gaingiin Society is an initiatory association (Bernardi 1985). It is a system of names, masks and rules that affords its members veiled agency in society. It is made up of seven age grades, and the membership of each consists of one or several cohorts (orub) of men who are said to have been born about the same time. Every grade is collectively named after the group of spirit masks (gaingiin) it holds. Adjacent grades are related through matrilateral kin ties. Mothers' brothers have junior partners who are classificatory sisters' sons. They refer to themselves, however, as 'fathers' of the latter whom they call 'sons'. In precolonial times, the ethos of which the masks still manifest, 'the right to give battle...[was] retained...in severalty' (Sahlins 1972:171). Intertribal relations were then self-governed, and each village was defended by its male cult. The Gaingiin Society, then, served the male cult and the community. It trained youth in the skills and defensive postures appropriate to the ethos of warre when 'every man is Enemy to every man' (Hobbes 1972:223), prepared them for the rigours of initiation, and instructed them in its organisation. At the same time, its masks asserted authority in certain circumstances in order to facilitate the accomplishment of specific ritual goals. In the past 100 years or so, the Gaingiin Society has persisted, but it has come to serve different functions, the community having long since conceded its reliance upon the military services of the male cult to the state and having been thoroughly influenced by petty capitalism and missionary Christianity.

In 1981-2001, the seven grades in the Gaingiin Society still possessed their masks. Each one had the right to make and don masks that concealed its wearer's domestic identity, at least pseudo-anonymously. ${ }^{3}$ The masks went on being imagined as warrior spirits. As spirits, they are mute and bearers speak not a word while appearing in them. As warriors, they may attack anyone junior in grade to themselves. Young men in the entry-level grade, whose masks are called Gaingiin (see Figure 3.1), constantly stalked village avenues and plazas chasing and menacing uninitiated children with throwing sticks. Children would flee (in delight). Gaingiin is a well-loved, but earnest and scary, bogey who associates the public square, at least among children, to the aforementioned Hobbesian posture, made into an intense game of chase. Once in a while, a parent might hand over a toddler to the monster, who might be seen holding it up over its head, as the child screams in terror, struggling to be given back to its mother or

3 The masks, however, run barefoot through the tidal flats and leave footprints that are said to be universally recognisable. 
father. When Gaingiin does so, the toddler will cling to the parent as if for dear life. Public space is alive with threatening spirits whose names mothers and fathers yell to bring children to heel when they do not listen.

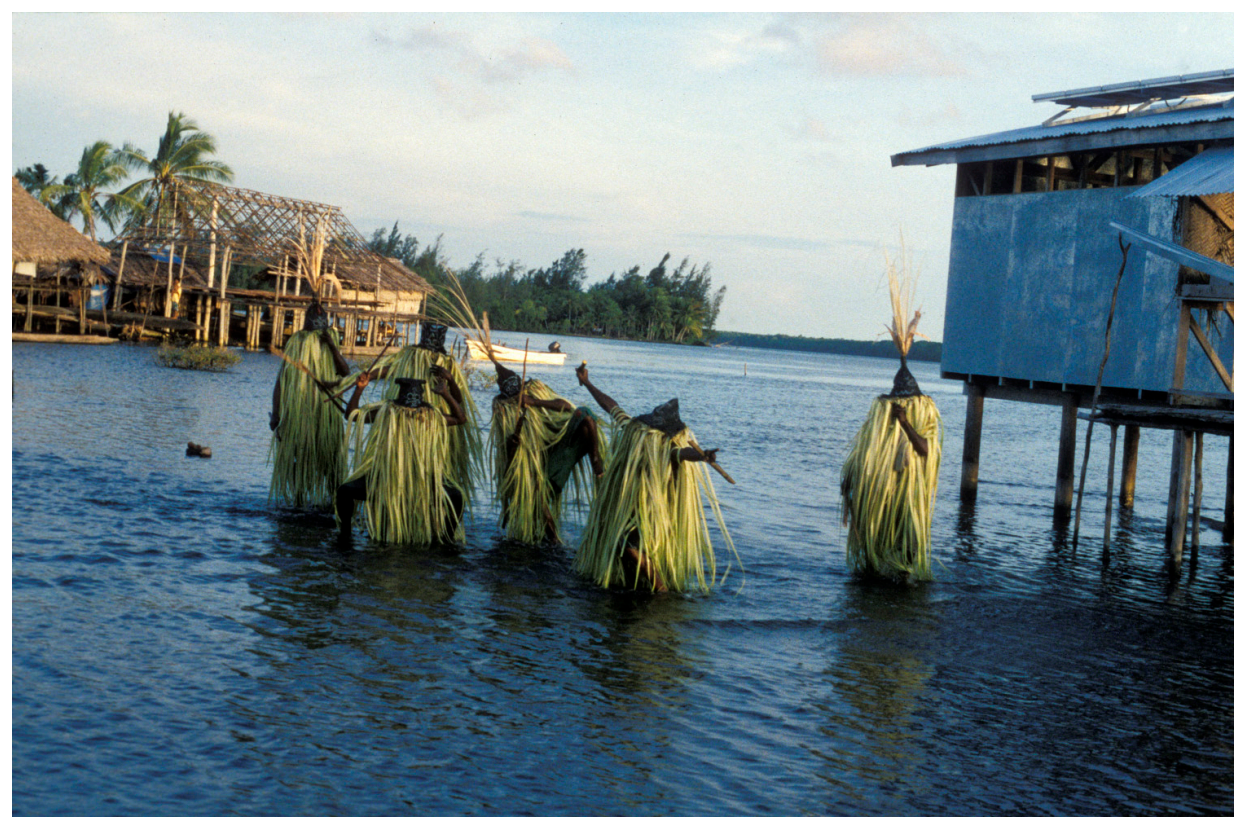

Figure 3.1 A proud, newly initiated Gaingiin grade

Photo: David Lipset, 2001

The Dimbwan and Bananain masks (Figures 3.2 and 3.3) belong to two of the top grades in the Gaingiin Society. As bearers of its senior authority, who oversee a measure of civitas, they have a right to install a community-wide taboo against the harvesting of coconuts. That is, the two spirits may (temporarily) supersede corporate property rights - a nontrivial privilege in pre-state terms. During the run-up to major feasts, such as end-of-mourning rites or initiations, ritual sponsors may oblige Dimbwan and Bananain to make property markers (jaba'iin) out of the midribs of sago fronds (saidug). Grade members beat them so that yellow streamers, which are $90 \mathrm{~cm}$ or more long, dangle from the stiff part of the midrib that is left. The two masks will then erect the jaba'iin at the openings of channels and footpaths leading to coconut groves, which are then said to become 'their property'. If someone steals coconuts, the Dimbwan and Bananain maskers may chop down the coconut groves in which the theft has taken place and attack the village at large with spears. In addition, the two masks provide 'security'. In 1993, for example, I saw Dimbwan 'escort' a group of women through the coconut groves to a waterhole and then bring them home. ' $\mathrm{He}^{\prime}$ did so, it was said, to make certain that no coconuts were stolen along the way. The two masks also have the right to suspend their taboo temporarily and 
allow the gathering of coconuts, should a contingency arise, such as a drought or a funeral. When the Dimbwan grade agrees that sufficient coconuts have accumulated in 'their groves' to supply a pending feast, they will secretly adorn themselves with flowers in the bush and return to the village to declare by their appearance that final preparations for the feast should start.

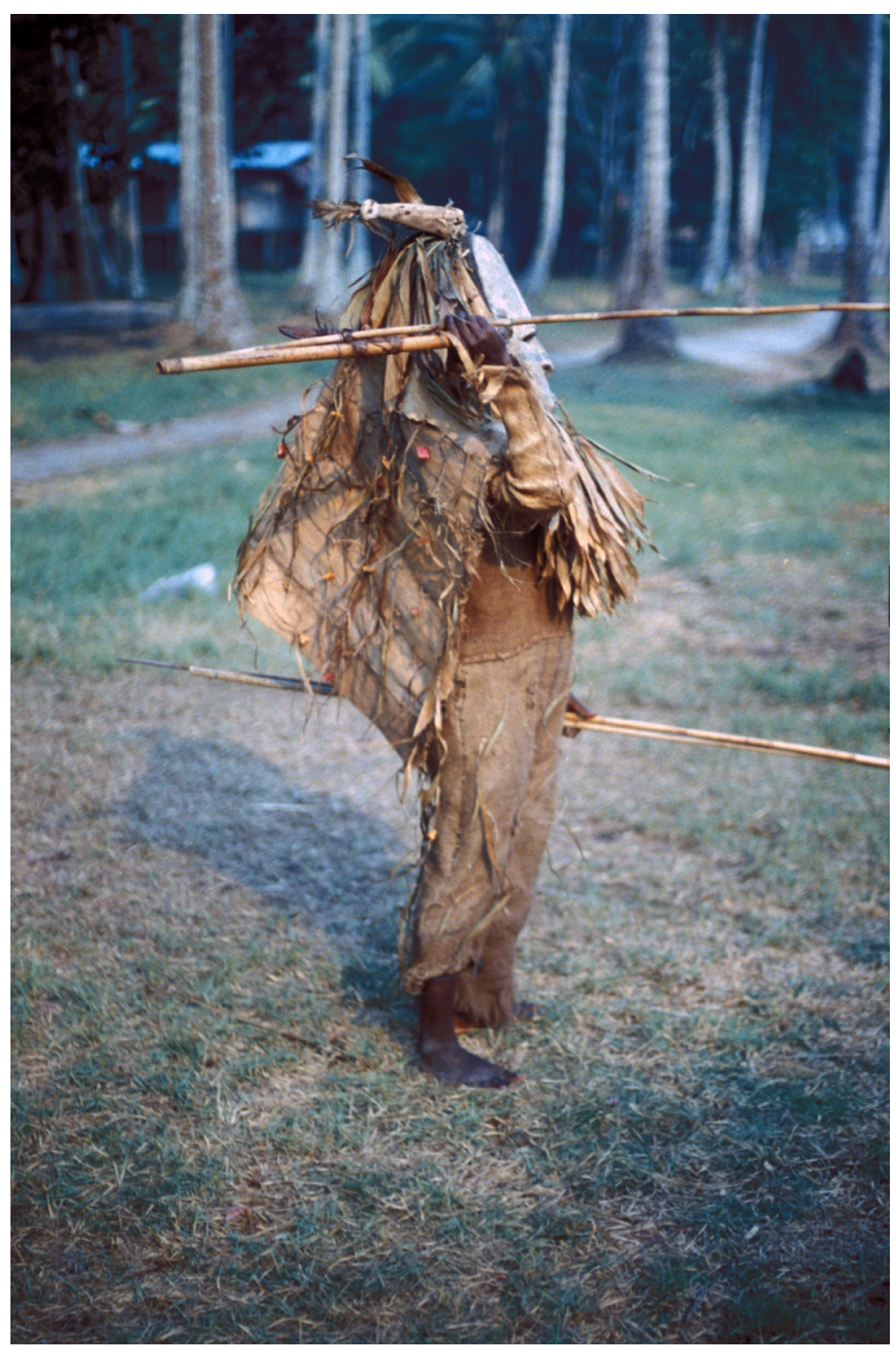

Figure 3.2 Bananain

Photo: David Lipset, 1993 


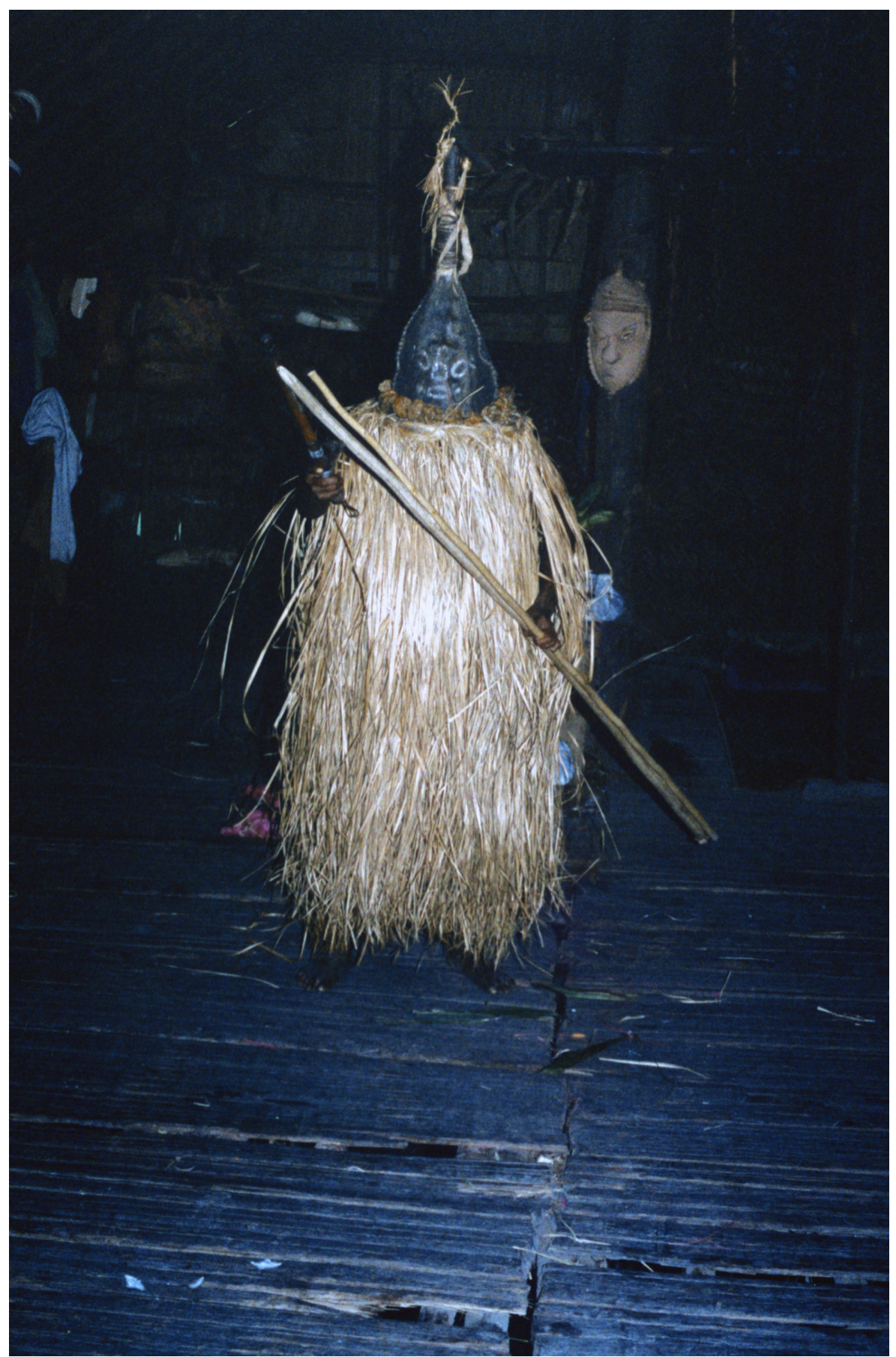

Figure 3.3 Dimbwan

Photo: David Lipset, 1993 
The taboo the senior masks install exerts a supra-social, yet indirect, kind of authority over the whole community in a flexible register that is named and masculine, but masked and numinous rather than human. The question is: authority over what? Over property represented as coconuts. Coconuts are property, to be sure. In Murik terms, however, they are also associated with the breast. That is, coconuts evoke the desire of the other prior to the intervention of the Name-of-the-Father. This connection is surely visible (and audible) in the way Murik people literally suckle coconut milk (dapag arum) out of them. It is made explicit in the effigy of a spirit woman called Namiit, who appears in a phase of male-cult initiation, her breasts then being represented by coconut half-shells attached to her torso. The reference is also made with grotesque inflection during a rite of reversal called noganoga'sarii. Following the death of a successful lineage head, women and men attack each other, armed with coconut half-shells filled with a fetid mixture of animal faeces and mud that they try to stuff in the mouths of affines (see Lipset and Silverman 2005). More data could be adduced about the maternal symbolism of coconuts (see Lipset 1997:279). Suffice to say that the taboo forbidding their harvest begins to suggest an authority that might be likened to a Lacanian injunction tabooing the desire of the other revised in terms of a Melanesian semiotic-for example, the ethic of reciprocity and interdependency of a culturally particular variety. The compensation in return for promotion into the most senior grade confirms this interpretation.

\section{'The Snake Caught Me!'}

Until the 1960s, taking the Dimbwan mask demanded a 'total prestation' (Mauss 1973:3) from the Bananain maskers. As I indicated above, each member of the senior grades has a junior partner in the adjacent grade who is his classificatory sister's son, but who is ritually addressed as a 'son'. The senior man's 'son' eventually is granted rights to the mask. In order to compensate his ritual 'father' for grade taking, the leading 'son' had to permit his 'mother' — for example, his wife ${ }^{4}$ - to 'marry' his 'father' in the Dimbwan cohort. The provision of a wife's sexual services was called 'sending [lit. doing a] his skirt' (dago'timariin) to his counterpart. That is, a husband would ask his wife to offer to engage in sexual intercourse with his senior masking partner. Should she agree, her expression of desire for the 'father' set further ritual exchanges in train that would culminate in the grade taking of the whole cohort. ${ }^{5}$ In 1981, the late Murakau Wino sketched out the sequence to me.

4 A wife may be addressed or referred to as 'mother' in Murik kin terminology.

5 See Thurnwald (1916) and Fortune (1939) for two other accounts of the exchange of sexual intercourse in the context of warfare and male-cult ritual in the Sepik region. And see also Lipset (1997) for a discussion of wife lending in the context of the Murik male cult. 
Husbands and wives belonging to the Bananain grade would paddle across the lakes to collect sago frond midribs. Upon returning to the village, they would pile them up in an isolated, private spot in the coconut groves. That night, the leading member of the junior grade would 'send his skirt' to his 'father' (his classificatory mother's brother). The provision of sexual intercourse by the junior partner's 'mother' was said to 'pick out the thorns of the sago frond caught in his feet'. The woman would go to him carrying a sago frond over her shoulder. Placing the base of the frond on his shoulder, the husband's 'father' acknowledged her desire.

The couple would go off together to the pile of sago fronds that were to be used to make the raffia-like cloaks of the new Dimbwan masks. The couple would have intercourse there. The woman would then return to her husband and declare: 'The snake caught me!' (Ma wakun tenangakum). The leader of the junior grade - that is, the man who had just sent his wife-would then gather the rest of the couples in the cohort together to prepare a feast for the whole senior grade who were to instruct them how to assemble the Dimbwan costumes.

The phallus, or 'the snake', as I say, was not meant to inseminate the wife of the junior masker. That is, it was not meant to impregnate the woman; it was rather offered as a phallic pleasure given in return for the work he and the senior grade would do to prepare the masks for the initiates. Its reproductive significance was, rather, afforded transactional meaning. The wife's/mother's sexuality was imputed reciprocal use value; its pleasure, as well as the husband's implicit resentment at temporarily having to relinquish (rights to) her, were compensation. By having intercourse with the junior woman, the senior masker became obliged to yield his and his grade's paramount status in the Gaingiin Society. They would initiate the junior cohort and retire. Now symbolism in the grade-taking rite does indeed evoke birthing imagery, as we shall momentarily see, so in this sense, the formulation of sexuality as exchange, and the metaphor of replacement, becomes a culturally specific formulation of reproduction, which of course recalls the great Trobriand ethnography of Annette Weiner (1978, 1979, 1980).

Weiner was concerned with expanding the temporal and material purview of cycles of reciprocal exchange. Her central point, however, stressed the importance of incorporating local concepts of exchange, wherein the Trobriand concept of reproduction as 'replacement' became her exemplar - 'replacement' being their gloss for the elaborate and extensive transactions that result in sociological succession (Weiner 1980:78f). My interest in the Murik notion of 'replacement' in the Gaingiin Society in post-colonial Papua New Guinea obviously differs 
from Weiner's focus on exchange theory. I am interested in the relationship, and the connections, between pre-state and post-colonial meanings of masculinity that I compare and contrast with the Lacanian phallus.

So as to petition entree into the senior signifiers in the Gaingiin Society, instead of being cut off from the desire of the other by the Name-of-the-Father, a junior masker would voluntarily give in to symbolic castration by conceding 'his mother's desire'. What is more, the senior man would not permanently taboo his ritual 'son' from maternal desire, but would rather return her desire to him. She goes back to her husband, happily celebrating his partner's phallus; 'The snake caught me!' she would exclaim, the announcement of which brought with it the prestige and authority of her husband's partner's mask. The temporary transfer of conjugal rights opened the door of initiation to the junior grade. The dependency of the phallus upon their 'mother's desire' could not have been made any more plain in this scenario. But instead of being colonised by her loss into the emptiness of the Symbolic, the door led elsewhere. It led to another phallus.

\section{8: Installing a coconut taboo}

Giving 'skirts' for the purposes of compensating initiators ended in the Gaingiin Society when a new gift-money-was substituted. In order to argue that money became a signifier of the pre-state phallus in this context, and eventually that this substitution belongs to a larger itinerary of the signified, I now return to the late 1980s, only a few years after Tuzin found Ilahita in the throes of a messianic revolution that had left cultic masculinity in ruin. At that time, Lissant Bolton, Kathleen Barlow and I had undertaken the Sepik Documentation Project, for which we were buying contemporary objects for, and documenting existing collections in, the Australian Museum (Lipset and Barlow 1987). As our concomitant theoretical aim was to investigate changing concepts of value in intertribal trade, we called on selected villages along the north coast and on the Lower Sepik and interviewed people about historical and contemporary exchanges, in addition to marketing and eliciting data about photographs of museum objects. When we got to the Murik Lakes in August 1988, we bought a Yangoron costume in Darapap village, the Yangoron masks being a family of spirits that belongs to a mid-level grade in the Gaingiin Society, which had been imported from Mushu Island up the coast to the west of the Murik Lakes. They appear in public from time to time dressed in coconut-bark capes and overalls. 'Father' and 'son' masks are distinguished (from their 'mother') by big, erect phalluses that bounce up and down as they dance among bemused audiences who might serenade him (Figure 3.4). That is, the Yangoron family plays a comic, rather than a threatening, role in the community. 


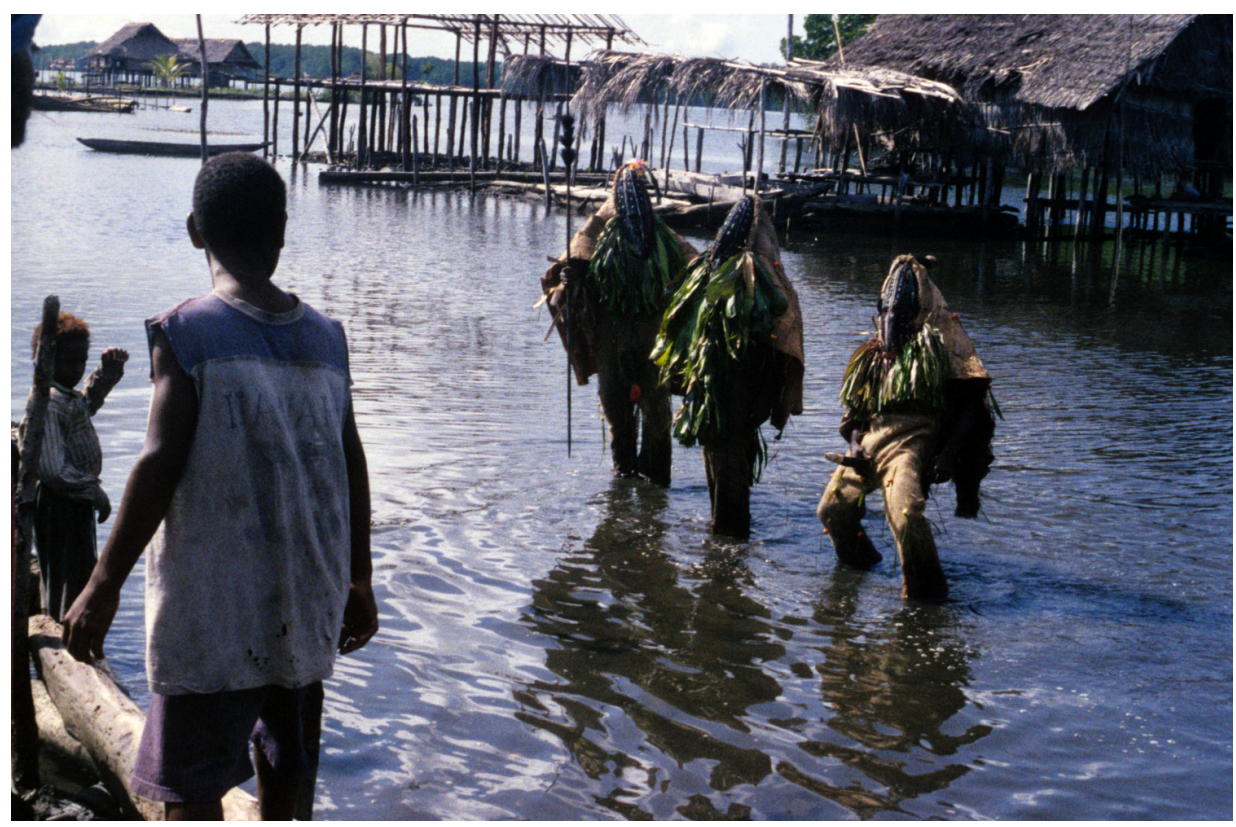

Figure 3.4 Yangoron (right) with his parents who are escorting him to the boat

Photo: David Lipset, 1988

In the course of negotiations to buy the 'son' from his grade, I went to a meeting in the male cult house. The men of the Dimbwan masks were then being tasked with the installation of a taboo forbidding the harvesting of coconuts in the run-up to a female-cult initiation rite that was pending (see Barlow 1995). As men waited for a feast that the rite's sponsors were preparing, rather heated discussion arose.

The Dimbwan grade, a man called Ker began to complain, had not fed the Bananain masks [of which he was a member]. He did not want the masks of his grade to gather stalks of sago palm and pound out fringe from them (jaba'iin), so the senior grade might then erect them as taboo markers. Wapo, a senior man in the Dimbwan masks, offered [to sponsor] a meal for the junior grade in the name of his cohort, so that the taboo could be properly installed.

The exchange, in which the junior masks should work for the senior masks in return for a feast and ritual support, is normative in Murik kinship. Youth expect that age will nurture them in return for which they will feel obliged to serve their elders. Ker was upset, in other words, that his grade was hungry. So why should they work? 
Ker stood. He demanded to be initiated into the Dimbwan grade and complained that too many junior men had been promoted ahead of him. A firstborn son, he went on to admit, could replace his father in the senior man's grade, especially should he have grown old and his 'wood had rotted'. Sitting next to me, Sivik, who was a generation younger than Ker, whispered that he himself had taken his father's place in the Dimbwan grade just this way. Sivik pointed to Kaibong, younger than Ker, who had been promoted ahead of his cohort after giving his wife to his mother's brother, and had taken the opportunity to bring several junior men along with him, but not Ker.

Ker's reproach - that he had been ritually ignored by the senior maskswas based on an assumption, again coming from kinship norms, that needs to be made explicit. Not only are youth expected to be demanding, age fully acknowledges a desire to spoil them. But never vice versa. Age ought not ask anything of youth. To do so would degrade the self as 'young'. Cooperation from youth may be had only indirectly through strategic acts of care and nurture. Ker might have been grumbling, in other words, but as he belonged to the junior mask, his grievance was culturally normative. In Lacanian terms, if discourse arises from the loss of the other's desire, it signifies the empty phallus. From this standpoint, the generous presence that the youth would demand-expressed in age-differentiated norms of generalised reciprocity-recalls the other's absence and arouses desire for her desire all the more. Initiation into the senior mask, however much of a deprivation it might require, must signify both the mother and the castrating loss of her desire, thus binding the subject to the signifier, as Lacan's epigraph had it. The phallus - both symbolic and organic - is therefore never far to seek in the Gaingiin Society.

To wit: promotion in the Gaingiin Society is not fixed by chronological birth but is negotiable. Why is grade skipping warranted and how is it indemnified? It is justified in terms of the phallus. The substitution of the firstborn son, or other youth, for an ageing father was meant to preserve the phallus, not as metaphor, but now as organ, as a literal recipient of the desire of a junior masker's wife. It is also justified by the ambition of a junior man wanting to advance ahead of his cohort, which required sending his 'mother' to have intercourse with his 'father'. Grade skipping denoted the phallus, albeit in a characteristically Melanesian register. The subject enters a new level of 'the Symbolic' not by having to give up the desire of the other to the Name-of-the-Father but rather by trading upon that desire with 'him'.

Back at the male cult house, the co-sponsors of the women's initiation rite, Kaibong and his co-wife Tasi, were serving a meal. Its purpose was to obligate the senior maskers to taboo the gathering of coconuts so enough would be available to fulfil ritual needs. A leaf-covered set of plates filled with rice or sago 
pudding and garnished with fish was set out in the middle of the floor. Discussion continued about grade taking in the Gaingiin Society. Money, the men agreed, had replaced 'skirts'. Having previously sent his wife to his mother's brother, as I had been told, Kaibong had become the leader of the Dimbwan masks. In addition, to honour the retiring grade with a feast and aragen - the ceremonial porridge made of coconut milk and dried coconut meats-Kaibong now set the price for grade taking at $\mathrm{K} 200 .^{6}$

Kaibong (standing before the meal): 'This little food [I now offer] is from my wife [and is meant to compensate Dimbwan] to set up the taboo markers (jaba'iin) in both Darapap and Karau [villages].'

Mathew Tamoane (a Bananain member) stood: 'Our initiation [into the Dimbwan masks] should [take place] right away! It will take a bit of time to collect money from the members of the grade. We must take Dimbwan now and pay later!'

Kaibong (in anger): 'You [Bananain masks] must pay us first!'

Murakau (as a senior member of Dimbwan): 'Right!'

Ker (as Bananain leader): 'Food is easy. We can give you food now. But money is a little harder. Can you give us a little time for it? The feast will be staged soon. If we want to get the money together, there will not be enough time to gather a lot of dry coconuts for the [ceremonial porridge].'

Wapo (a senior member of Dimbwan): 'We won't allow debt. We want the food and the money at once. Otherwise, we will just put the Dimbwan [costumes] together and wear them ourselves!'

Ker: 'I will go to [town] and come back and get the jaba'iin [sago fronds for the coconut taboo and the costumes] and beat them with my grade.'

[The Dimbwan grade divided up plates of food among themselves and began to eat, acknowledging their obligation to set the taboo by doing so.]

The standing of the Gaingiin Society was relatively uncontested in 1988. Even Seventh-Day Adventist men, unlike the revivalists in Ilahita, were clearly not out to disband it. Ker, Wapo and Mathew Tamoane, who advocated holding the grade-taking rite as early as possible, were all leading Seventh-Day Adventists. Neither did anyone dismiss the Gaingiin Society as a waste of time that could be better spent on modern pursuits, such as the villagers' small-scale fishery.

6 In 1988, PNG K1 $=$ US $\$ 0.85$. 
Instead, men assumed that the Gaingiin Society would and ought to go on. Their issue was how to reproduce it within the post-colonial context; in other words, how to convert the value of the phallus - for example, a 'mother's desire' - into money. How many PNG kina was a 'skirt' worth?

\section{Grade Taking and the Metaphor of Money}

The grade taking took place a few days later. Unfortunately, I had left Darapap by then to go back upriver to the Catholic Mission at Marienberg, where my Australian Museum colleagues and I were based. I did manage to collect one account of what took place when I subsequently spoke to Joshua Sivik, one of the retiring maskers, shortly thereafter.

The Dimbwan grade decided that K200 was too dear. We cut the price in half. K30 was then paid us, leaving the rest as debt. Enoch, Ker and [another man] each paid K10 and became leaders of the grade. Kowre and Sauma [two senior men] accepted the money. The rest of us were not paid. Sauma gave his share of the money to Kiso, his wife, because she had intercourse with his mother's brother.

In the history of the Murik phallus, this substitution had already taken place in several other contexts. Now it was confirmed once again. The currency of the post-colonial state replaced-and was thus held to be functionally equivalent to - sexual intercourse. Money became a metaphor in the sense that its association with 'skirts' was that between two separate domains of meaning (Lakoff and Turner 1989:103). Ethically, what kind of metaphor had money become? It did not tip a Weberian shift from an otherworldly sexuality into an erotic sensuality $(1946,1978)$. Nor did it tip the arrival of a modern subjectobject distinction. Inner life did not instantly become rationalised. From transactional and sociological viewpoints, the metaphor of money had not been exchanged between strangers. Although the Australian Museum did buy the Yangoron mask, the money for the Dimbwan grade taking was paid to mothers' brothers who were clearly not out to maximise profit. The senior grade offered a 'number two' price because they wanted to help the junior grade rather than exploit them. The money, to put it plainly, was both a gift that signified the Murik phallus and the universalist and rational phallus of modernity.

Let me finish discussing my informant's narrative of the grade taking. The senior Dimbwan maskers gave way to their junior counterparts whom he called the 'children's grade' (naje'orub). In the event, the ritual work of installing the coconut taboo was combined with the initiation of the Bananain maskers. 
They gathered sago palm fronds in a motor-canoe. Both husbands and wives of the senior grade then beat the fronds [for the cloaks of the costumes]. The men assembled about twelve Dimbwan costumes inside the Male Cult Hall. Classificatory mothers' brothers made specific masks for their sisters' sons. I made the mask called Saboganap for Komsing and made Dagodago for Luke. The Bananain grade presented a feast to the Dimbwan grade for this work. The Dimbwan grade then beat the junior grade as they crawled through a tunnel of their legs.

Ker paraded through the village as Mwaraynor with the Mindamot lineage insignia (sumon) as a headdress. Coconuts were broken in his path to honor the insignia. The rest of the newly promoted Dimbwan masks followed him. They were trailed by two masks, called their 'mothers'.

The senior, retiring grade then made aragen, the ceremonial porridge, for the new Dimbwan grade to oblige them to begin the coconut taboo. Eight coconuts were harvested to prepare the porridge. Next day, six Dimbwan masks went to Karau village to install a taboo on groves there. The grade was well fed.

The relations of production between the grades, that is, had assumed anything but a 'fantastic form of a relation between things' (Marx 1990:165). Rather, the prevailing ethos was one of use value, domestic sociality and personification. The two grades were classed in patrifilial terms as 'fathers' and 'children'. Married couples worked together to prepare the fringe for the costumes as a cohort of masked spirits. The Dimbwan masks were individually named, and one mask, called Mwarenor, was decorated like a firstborn initiate privileged to display lineage heraldry (Lipset 1990). The initiation of the junior grade by the senior masks mimicked a rite of passage in to the Symbolic, on the one hand, but on the other it also invoked a kind of grotesque birthing imagery. The 'sons' succeeded the 'fathers' by crawling through a gauntlet of legs. The transfer of the masks seemed to recreate the phallus desired by the other.

The retiring Dimbwan maskers fed and were fed by their successors, who then installed the coconut taboo in two villages. When money replaced 'skirts', the relationship between people and masks remained relatively stable, in other words. The masks did not become governed by relations between people in a state of independence from each other. Nor had the ethical position of the subject suddenly become secularised. Outer life did not suddenly become despiritualised. Nor had inner life suddenly become spiritualised. The masks of the Gaingiin Society had rather moved the subject into a neither/nor - not quite one, not quite the other-world between the Murik and post-colonial 
Symbolics. How did the masculinity of the Dimbwan mask fit the broader register of substitution and enchained signification in contemporary, postcolonial Murik culture?

Recall that Tuzin regarded the actions taken by revivalist Christians against the Itahita male cult in the mid-1980s as a symbolic act of 'murder' that 'killed' ritual masculinity, not as a metaphor, or chain of signification, by which the two institutions continued to reference each another. Culture in Ilahita was then divided up between rival nostalgic and depressed post-cultic men and the revivalists, who were desperately preparing for the Second Coming. As such, the millennial time then in play permitted little other than a perception of rupture and masculine anomie.

Facilitated by the cultural concept of replacement introduced earlier, at least two, interrelated chains of signification can be distinguished in Murik. The one dis-embeds and severs the cultic phallus from the Symbolic, by referencing nothing other than the commodity and the market, while the other makes a metaphor of the cultic phallus by associating modern ideas, objects and persons with it. These two chains of signification converge, I suggest, in a rather more complicated tone of masculine alienation than the tragic one Tuzin lamented so eloquently as having overtaken Ilahita.

\section{Conclusion: The phallus in post-colonial Murik}

Like Sahlins' Hawaiians (1985), as well as many Pacific peoples, the Murik began to call whites 'yabar goan', or children of the yabar spirits, at or soon after first contact, the yabar being a superior class of ancestor spirits who possessed great powers to transform the landscape and persons. In Durkheimian terms, the yabar were a collective representation of autochthonous mastery over space and society. In Lacanian terms, the yabar represented a lack, or a desire for the lost desire, of the other. The yabar spirits have long since disappeared from Murik animism, but the term yabar goan certainly remains in widespread use. Indeed, 'white man' is the most commonplace meaning of yabar, although not with a presumptively racialised valence (cf. Bashkow 2006). I have repeatedly heard it in reference to PNG nationals. The concept of yabar would thus seem to denote the technological space of urban capitalism where punctual subjects work for salaries, purchase goods and travel in yabar 'canoes' - cars, boats and airplanes regardless of skin colour. The resources of the yabar-both as space and as social category - are viewed as morally problematic, challenging and difficult to deal with. Although they recognise and appreciate its vigour and wealth, both villagers and peri-urban Murik complain that they are made uncomfortable by it, not provisioned, protected or advanced by its meagre attentions. The moral 
agency of the yabar spirits might have exited Murik cosmology, but the contour of their enormous powers remains. Yabar has become a null signifier in their Symbolic. At the same time, yabar has come to refer to modernity. This semantic extension, I argue, exemplifies a chain of substitution that does not just signify rupture, but rather doubles the absent desire of the other, thus to build upon that archaic castration.

Let me cite several substitutions - large and small — of this emasculating kind. Today, men will prevail upon any makeshift kind of sealable container-for example, glass jars or little metal tins - to hold the lime powder they use when chewing betel-nuts. In the past, they had gourds engraved with geometrical designs, which only initiated men used, and which they named for the overseas lover who had given it to them (see Figure 3.5). As metaphors of a phallus contingent upon the lost desire of the Murik other, the jars and tins no longer refer to 'her' lack. Now, they refer to a second lack, which figures men as poor and unsophisticated 'grassroots', in the national slang (see Figure 3.6).

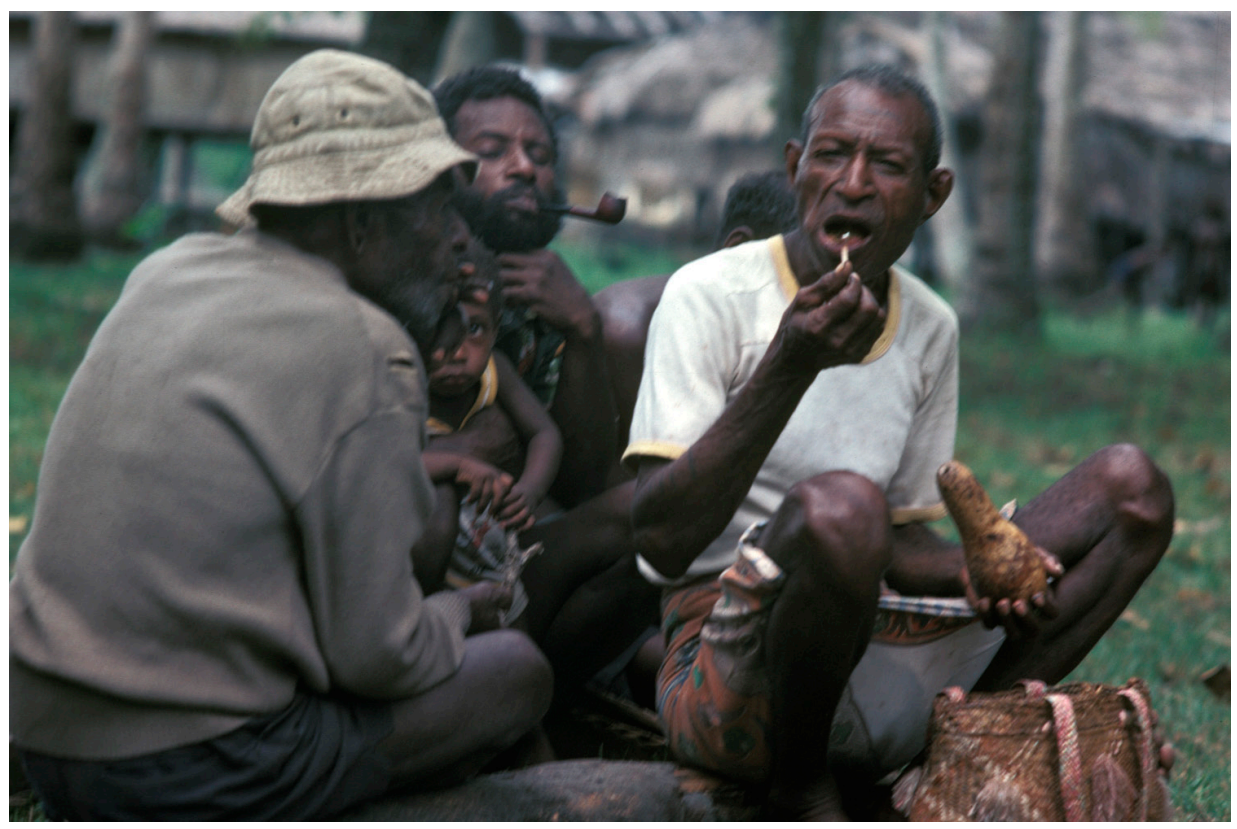

Figure 3.5 Man with lime gourd

Photo: David Lipset, 1988 
3. 'Skirts-Money-Masks', and Other Chains of Masculine Signification in Post-Colonial PNG

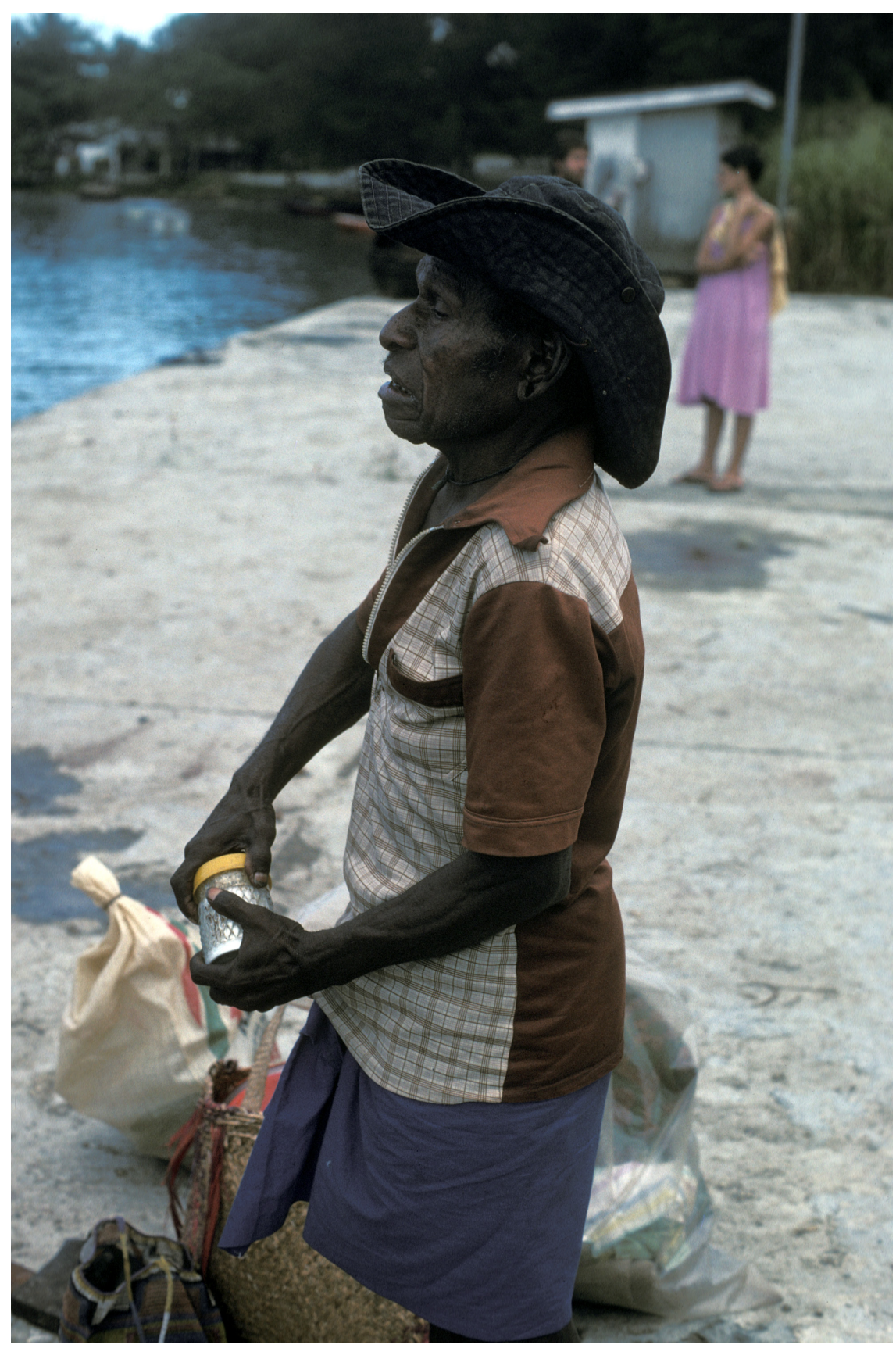

Figure 3.6 Man with glass jar for lime powder

Photo: David Lipset, 1982 
In pre-state society, rival moieties used to consecrate the male cult house (taab) by competing to ignite fire by friction, the victorious side then taking the honour of relighting the hearth fires in the community, all of which were extinguished prior to the event. This was part of an elaborate ritual dialogic between male and female, in which the male cult asserted a claim on maternal nurture (and the female cult answered by attempting to shake down the whole building by its pilings). Today, men still talk about this moiety competition in these very terms in connection with the consecration of new cult houses that are being built. But the relationship of the male cult to women's cooking and the illumination of the night, while still relying on firewood gathered from the Murik Lakes, have become mediated upon disposable butane lighters, kerosene, hurricane lamps and battery-powered flashlights. These commodities, as I propose, both do and do not refer to the male cult and 'his' absent other, the 'skirts' with which its moieties 'fought'.

In the contemporary technology of sleep, we might see a similar itinerary of the masculine signifier. Today, men and women sleep (with children) inside mosquito nets bought in town. Until the mid-1950s, the Murik slept in long, dark hand-woven bags (arug), together with the skulls of grandparents. In the morning, as they crawled out, they took the relics and 'fed' them cigarettes and betel-nuts. The interiors of mosquito nets do not demark spaces that have become completely disconnected from the lineage because people interact with ancestors in their dreams. But of course they are disconnected from the division of labour, the weaving of the bags having been women's work. Today, moreover, people sleep on foam pillows. Pre-state pillows - headrests - were made of wood propped up by little bamboo legs. They were engraved with imagery of ancestor-spirits and their zoomorphic totems - pigs in particular. Only men manufactured and used headrests, which is why they expressed male desire. Foam pillows do not signify their ornate predecessors. Foam pillows are gender neutral. Qua metaphor, they do not signify the Murik phallus. They rather index (the low level of) Murik integration in consumer capitalism. Pillows, however, together with mosquito nets, butane lighters, kerosene lamps and flashlights, remain links in a signifying chain of masculine negation, or, in Lacanian terms, of symbolic castration.

Like the substitution of money for sexual intercourse in the Gaingiin Society, the chains of signification that circulate in post-colonial ritual exchange index a complicated, multi-level kind of masculine alienation. There is, for example, a category of valuables called mwaran that includes several kinds of prestige goods, such as tobacco, betel-nuts and pigs, as well as shell ornaments, and a wide variety of ritual services, the most important of which was the exchange of 'skirts'. The Murik speak of hereditary feasting partners who donate ritual mwaran as belonging to the 'valuables route' (mwara yakabor). Today, toea coins 
appear together with shells woven onto the aprons of loincloths they give malecult initiates. Instead of shell and teeth ornaments, appropriate mwara kin now place PNG bills on the chests of corpses soon after death for the deceased to use en route to the afterlife. In the past, the mwara kin used to give new loincloths, their apron panels painted with snake-phallus motifs (see Lipset 2009:57), to their partners as part of their provision of end-of-mourning services. Today, they give them new shirts, dresses and shorts. Disenchantment is certainly a reference of these clothes (Eisenstadt 1968), and use value is no doubt being dis-embedded by these commodities (Giddens 1990). They are, however, incorporated within, rather than displaced from, Murik social structure and its reciprocities, thus to evoke the symbolic castrations of the past in the present.

Perhaps most indicative of this chain of masculine alienation are the fibreglass boats in which the Murik travel along the coast from the lakes to the market town of Wewak. These little vehicles replaced the lineage outriggers whose prows were protected by male ancestor spirits and whose construction process and consecration rites also convened dialogue about the relationship of the cultic phallus to the desire of the other (see Barlow and Lipset 1997). Wooden planks, connoting an outrigger platform, are laid down to cover the floors of these dinghies (Figure 3.7), planks on which cargo is stored and people sit, continuing to divide themselves by gender as they used to do when riding on outriggers where men sat near the prow and women sat aft. Outboard motors have long since replaced coconut-bark sails. And their steering arms have long since replaced the big wooden steering paddles helmsmen used to hold (Figure 3.8), outboard motors whose power, of course, requires gasoline and clean sparkplugs rather than the desire of the other for the phallus (Lipset 2011:30-1).

Now, a bus named for a lineage outrigger carries fare-paying passengers through the streets of the provincial capital (Figures 3.9 and 3.10). As a metaphor of masculine alienation, the fibreglass boats, outboard motors and the bus all reference the pre-state castration for which they are substitutions. These objects not only rationalise the Murik phallus. They add a new lack onto the lack for which the phallus stood. They shift its dependency on the desire of the other, as in the Gaingiin Society, and move that lack into modernity, where money denotes both the old lack and the new lack. Tuzin's vision of 'the death' of masculinity in a millennial Ilahita finds a parallel in this chain of signification, to be sure. In this chapter, however, I have tried to show that the chain of masculine signification, the substitutions of local by modern values in Murik ritual exchange, material culture and semantic extensions might combine both continuity and discontinuity. The persistence of the phallus, as a paradoxical embodiment of deprivation in signification, suggests, rather than anomie, a rather equivocal picture of post-colonial masculinity, one that simultaneously fills out what is missing and represents its absence. 


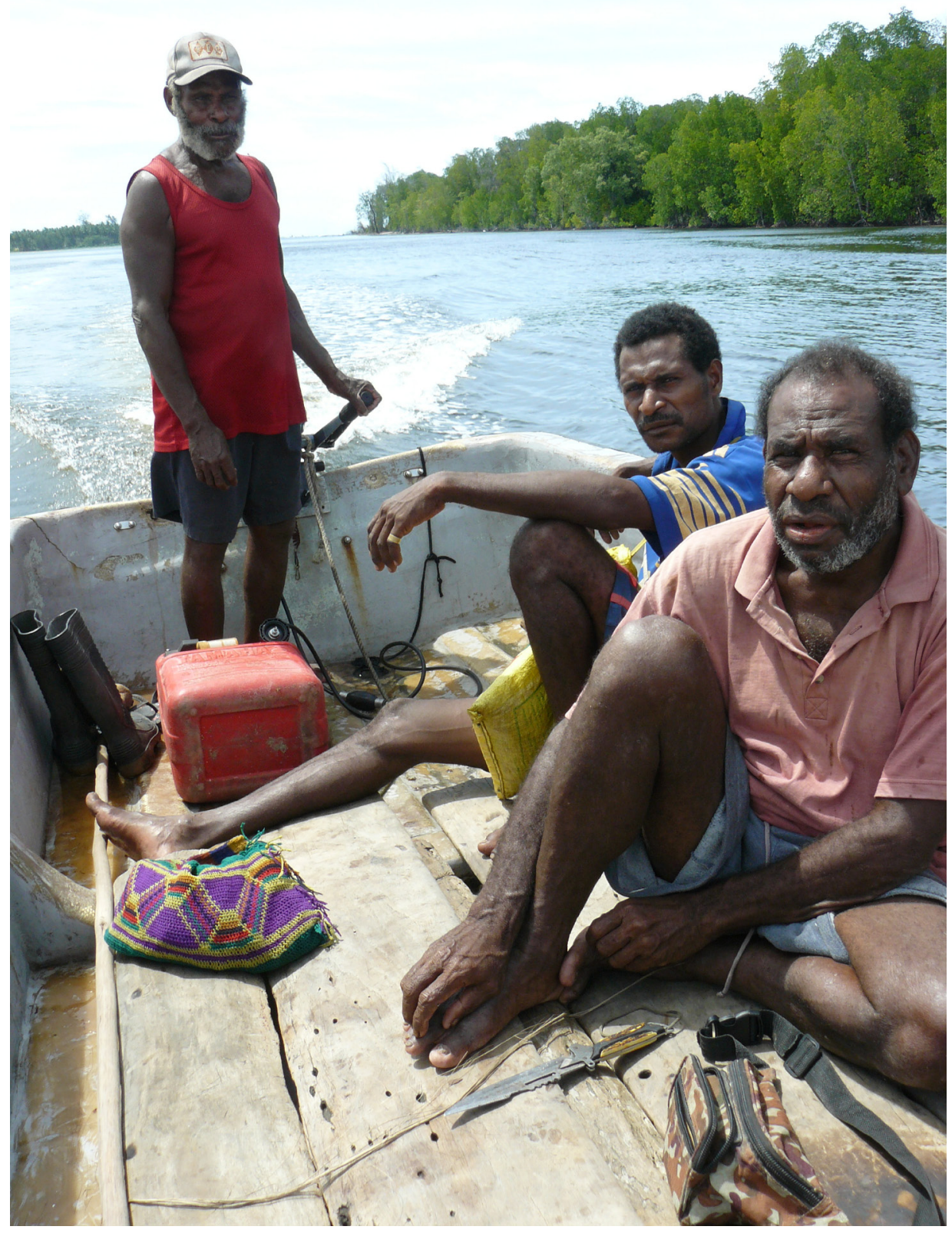

Figure 3.7 Man steering an outboard in a dinghy

Photo: David Lipset, 2008 
3. 'Skirts-Money-Masks', and Other Chains of Masculine Signification in Post-Colonial PNG

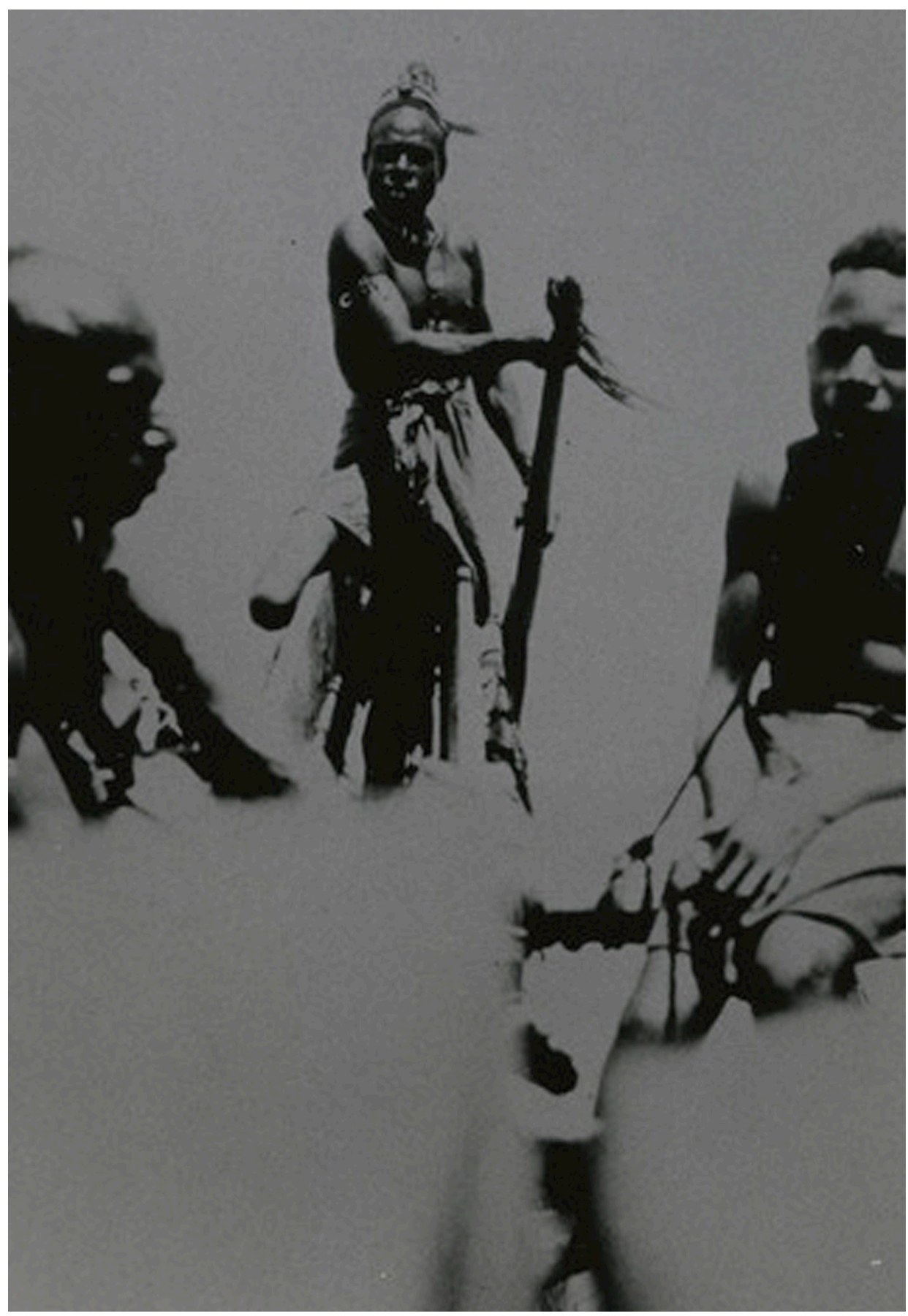

Figure 3.8 Helmsman with steering paddle in outrigger canoe

Photo: Franz Kirschbaum, 1908 


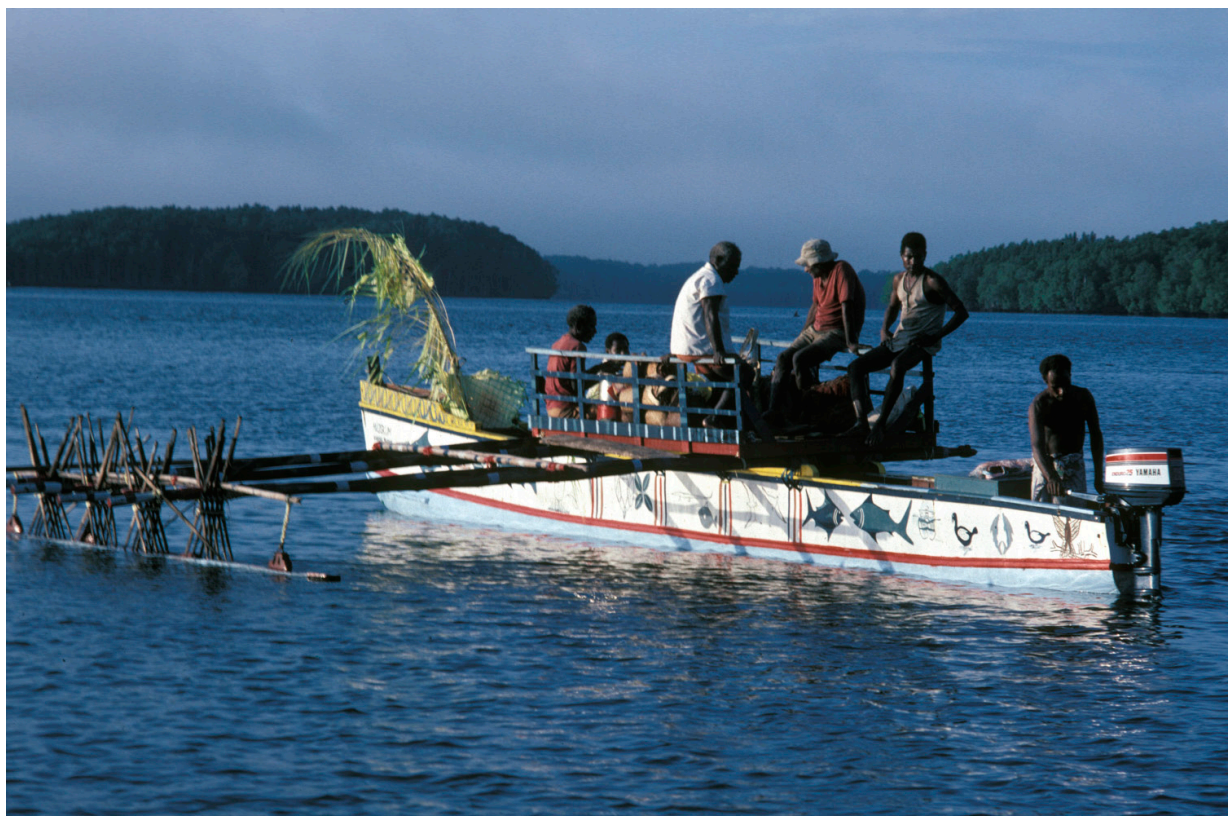

Figure 3.9 The outrigger canoe Diskum

Photo: David Lipset, 1982

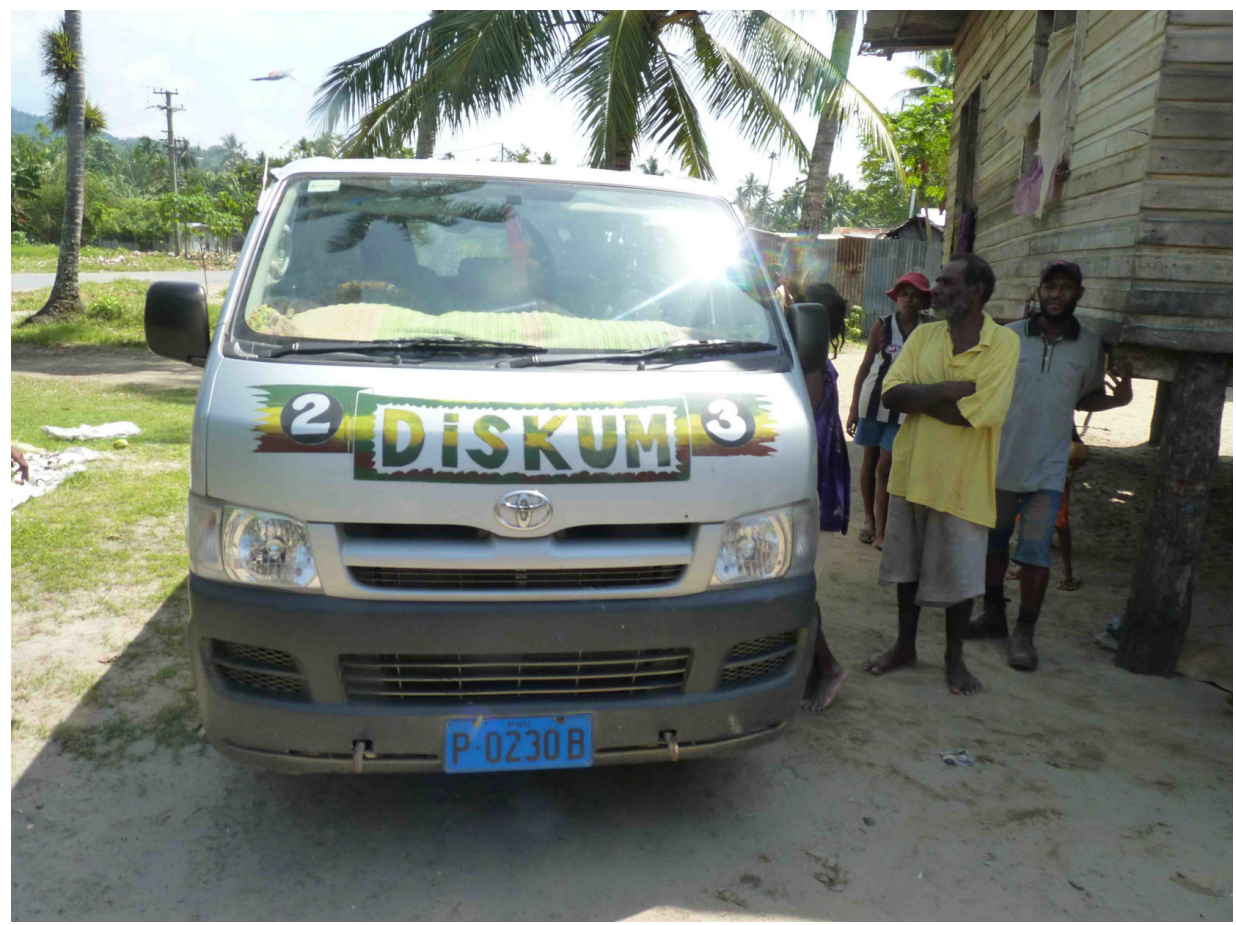

Figure 3.10 The bus Diskum 
3. 'Skirts-Money-Masks', and Other Chains of Masculine Signification in Post-Colonial PNG

\section{References}

Barlow, Kathleen 1985. The Role of Women in Intertribal Trade Among the Murik of Papua New Guinea. Research in Economic Anthropology 7:95-122.

Barlow, Kathleen 1995. Achieving Womanhood and the Achievements of Women. In Nancy Lutkehaus and Paul B. Roscoe (eds) Gender Rituals: Female Initiation in Melanesia, pp. 85-112. London: Routledge.

Barlow, Kathleen 2010. Sharing Food, Sharing Values: Mothering and Empathy in Murik Society. Ethos 38(4):339-53.

Barlow, Kathleen and David Lipset 1997. Dialogics of Material Culture: Male and Female in Murik Outrigger Canoes. American Ethnologist 24:4-36.

Bashkow, Ira 2006. The Meaning of Whitemen: Race and Modernity in the Orokaiva Cultural World. Chicago: University of Chicago Press.

Bernardi, Bernardo 1985. Age Class Systems: Social Institutions and Polities Based on Age. Cambridge: Cambridge University Press.

Brison, Karen 1995. Changing the Constructions of Masculinity in a Sepik Society. Ethnology 34:155-76.

Dumont, Louis 1986. Essays on Individualism: Modern Ideology in an Anthropological Perspective. Chicago: University of Chicago Press.

Durkheim, E. 1984 [1933]. The Division of Labor in Society. Lewis A. Coser (trans.). New York: Free Press.

Eisenstadt, S. N. 1968. Introduction: Charisma and Institution Building, Max Weber and Modern Sociology. In On Charisma and Institution Building, Selected Papers by Max Weber, pp. Ix-lvi. Chicago: University of Chicago Press.

Fortune, Reo 1939. Arapesh Warfare. American Anthropologist 41:22-41.

Freud, Sigmund 1961. The Interpretation of Dreams. James Strachey (trans. and ed.). New York: Science Editions.

Giddens, Anthony 1990. The Consequences of Modernity. Stanford, Calif.: Stanford University Press.

Gregory, Christopher 1982. Gifts and Commodities. New York: Academic Press.

Hobbes, Thomas 1972 [1651]. Leviathan. Michael Oakeshott (ed.). Oxford: Basil Blackwell. 
Jakobson, Roman 1971. The Dominant. In Latislav Matejka and K. Pomorska (eds) Readings in Russian Poetics: Formalist and Structuralist Views, pp. 2330. Cambridge, Mass.: MIT Press.

Klein, Melanie 1932. The Writings of Melanie Klein. Volume 2. R. Money-Kyrle (ed.). New York: Free Press.

Knauft, Bruce 2002. Exchanging the Past: A Rainforest World Before and After. Chicago: University of Chicago Press.

Lacan, Jacques 1977a. Desire and the Interpretation of Desire in Hamlet. Yale French Studies 55-56:11-52.

Lacan, Jacques 1977b. Ecrits: A Selection. Alan Sheridan (trans.). London: Tavistock.

Lakoff, George and Mark Turner 1989. More Than Cool Reason: A Field Guide to Poetic Metaphor. Chicago: University of Chicago Press.

Leenhardt, M. 1979. Do Kamo: Person and Myth in the Melanesian World. Basia Miller Celati (trans.). Chicago: University of Chicago Press.

Lipset, David 1990. Boars' Tusks and Flying Foxes: Symbolism and Ritual of Office in the Murik Lakes. In Nancy Lutkehaus, Christian Kaufmann, William E. Mitchell, Douglas Newton, Lita Osmundsen and Meinhard Schuster (eds) Sepik Heritage: Tradition and Change in Papua New Guinea, pp. 286-98. Durham, NC: Carolina University Press.

Lipset, David 1997. Mangrove Man: Dialogics of Culture in the Sepik Estuary. Cambridge: Cambridge University Press.

Lipset, David 2005. Dead Canoes: The Fate of Agency in 20th Century Murik Art. Social Analysis 49:109-14.

Lipset, David 2009. A Melanesian Pygmalion: Masculine Creativity and Symbolic Castration in a Postcolonial Backwater. Ethos 37:50-77.

Lipset, David 2011. The Tides: Masculinity and Climate Change in Coastal Papua New Guinea. Journal of the Royal Anthropology Institute (NS)17:2-43.

Lipset, David and Kathleen Barlow 1987. The Value of Culture: Regional Exchange in the Lower Sepik. Australian Natural History 23:156-68.

Lipset, David and Eric K. Silverman 2005. The Moral and the Grotesque: Dialogics of the Body in Two Sepik River Societies (Eastern Iatmul and Murik). Journal of Ritual Studies 19(2):1-42. 
3. 'Skirts-Money-Masks', and Other Chains of Masculine Signification in Post-Colonial PNG

Lipset, David and Jolene Stritecky 1994. The Problem of Mute Metaphor: Gender and Kinship in Seaboard Melanesia. Ethnology 33:1-20.

Marx, Karl 1990 [1867]. Capital: A Critique of Political Economy. Volume 1. Ben Fowkes (trans.). New York: Penguin.

Mauss, Marcel 1973. The Gift: Forms and Functions of Exchange in Archaic Societies. I. Cunnison (trans.). New York: Norton Library.

Mbembe, Achille 1992. The Banality of Power and the Aesthetics of Vulgarity in the Postcolony. Public Culture 4(2):1-30.

Moore, Henrietta 2007. The Subject in Anthropology. Cambridge: Polity Press.

Nobus, Dany 1999. Theorising the Comedy of Sexes: Lacan on Sexuality. In Bernard Burgoyne and Mary Sullivan (eds) The Klein-Lacan Dialogues, pp. 105-24. New York: Other Press.

Robbins, Joel 2002. Becoming Sinners: Christianity and Moral Torment in a Papua New Guinea Society. Berkeley: University of California Press.

Sahlins, Marshall 1972. Stone Age Economics. Chicago: Aldine-Atherton.

Sahlins, Marshall 1985. Islands of History. Chicago: University of Chicago Press.

Said, Edward 1978. Orientalism. New York: Random House.

Strathern, Marilyn 1988. The Gender of the Gift: Problems with Women and Problems with Society in Melanesia. Berkeley: University of California Press.

Thurnwald, Richard 1916. Banaro Societ: Social Organization and the Kinship System of a Tribe in the Interior of New Guinea. American Anthropological Association Memoirs 3:253-391.

Tuzin, Donald F. 1997. The Cassowary's Revenge: The Life and Death of Masculinity in a New Guinea Society. Chicago: University of Chicago Press.

Wardlow, Holly 2006. Wayward Women: Sexuality and Agency in a New Guinea Society. Berkeley: University of California Press.

Weber, Max 1946. From Max Weber: Essays in Sociology. H. H. Gerth and C. Wright Mills (trans and eds). New York: Oxford University Press.

Weber, Max 1978. Economy and Society. Guenther Roth and Claus Wittich (eds). Berkeley: University of California Press. 
Echoes of the Tambaran

Weiner, Annette 1978. The Reproductive Model in Trobriand Society. In J. Spect and J. Peter White (eds) Trade and Exchange in Oceania and Australia. Special Issue. Mankind 11(3):175-86.

Weiner, Annette 1979. Trobriand Kinship from Another View: The Reproductive Power of Women and Men. Man (NS)14:328-48.

Weiner, Annette 1980. Reproduction: A Replacement for Reciprocity. American Ethnologist 7(1):71-85.

Wiener, James 1995. The Lost Drum: The Myth of Sexuality in Papua New Guinea. Madison: University of Wisconsin Press.

Young, Robert 2001. Postcolonialism: An Historical Introduction. Oxford: Blackwell.

Zimmer-Tamakoshi, Laura 1997. The Last Big Man: Development and Men's Discontents in the Papua New Guinea Highlands. Oceania 68:107-22.

Žižek, Slavoj 1989. The Sublime Object of Ideology. New York: Verso Press. 